\title{
The Significance of tabnith in the Context of Correspondence of Heavenly and Earthly Sanctuary in Exodus 25:9, 40
}

\author{
Blasius Abin \\ Faculty of Philosophy, Universitas Klabat \\ blasiusabin@unklab.ac.id
}

\begin{abstract}
The picture of the heavenly sanctuary/temple is that of a model for the construction of the

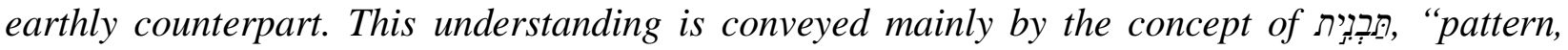

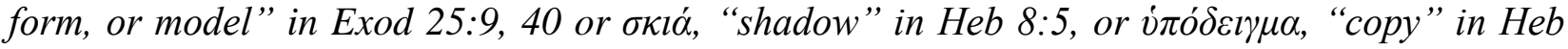
$9: 23,24$. It reveals that the heavenly sanctuary functions as the archetype of the earthly temple.

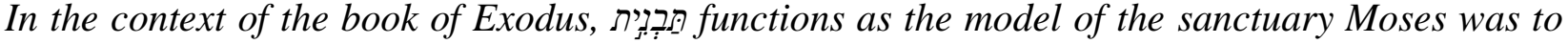
build on the earth. Moses was probably shown the heavenly sanctuary and a "model" of what he had to build upon the earth. The thus presupposes an original reality and, at the same time, also suggests an idiomatic correspondence between the heavenly sanctuary and its earthly counterpart.
\end{abstract}

Keywords: pattern; heavenly sanctuary; earthly sanctuary

\section{Introduction}

Sanctuary means an association of symbols and practices which evoke the presence of the deity in a piece of sacred space. ${ }^{1}$ This notion is usually, although not exclusively, expressed by the concept of an architectural building. ${ }^{2}$ There are cases, however, in which the idea of sanctuary may be evoked by related concepts such as holy mountain, and also references to worship and cultic allusions. ${ }^{3}$ This article, specifically discuss the correspondences of the heavenly sanctuary and the earthly through the usage of פַּבְנִית in Exod 25: 9, 40. In this regard, the need to

${ }^{1}$ Davidson noted that "since God is naturally the object of worship in the temple, it seems to follow that whatever God is mentioned in the temple context, the sanctuary/temple is in view." Richard M. Davidson, "Typology in the Book of Hebrews," Issues in the Book of Hebrews, ed. Frank B. Holbrook (Silver Spring, MD: Biblical Research Institute, 1989), 121-186.

${ }^{2}$ As Beale convincingly argued "a holy piece of geography or a sacred area can be considered a true 'sanctuary' or 'temple' even when no architectural building is constructed there." Beale, The Temple and the Church's Mission: A Biblical Theology of the Dwelling Place of God, New Studies in Biblical Theology 17 (Downer Grove, IL: InterVarsity, 2004), 97. In this connection, Beale pointed out that the worship areas built by the patriarchs feature five elements: God appears to them, they pitch a tent, build an altar, worship God, and made sacrificial offerings. The combination of these five elements "occurs only elsewhere in the Old Testament in describing Israel's tabernacle or temple." Ibid, 96.

${ }^{3}$ Aelred Cody, Heavenly Sanctuary and Liturgy in the Epistle to the Hebrew (St. Meinrad, IN: Grail Publications, St. Meinrad Archabbey, 1960), 15. Some scholars tend to see the heavenly sanctuary as a nonstructural entity, heaven itself, or just a metaphor for YHWH's presence. So, e.g., Beale, The Temple and the Church's Mission, 135, 152. 
investigate whether the functions of the heavenly sanctuary correspond with those of the earthly counterpart, the claim may be made, that there is a functional and idiomatic correspondence between the heavenly and earthly sanctuaries. ${ }^{4}$ An investigation of the Biblical text (i.e. Exod 25:9, 40) must be undertaken in order to determine whether such a nonstructural understanding of the heavenly sanctuary can be substantiated. Thus, special attention is given to the literary context, semantic, and syntax of the key text in the discussion in order to ascertain whether such a vocabulary connotes a structure entity in the lines of the earthly counterpart.

\section{Literary Context}

Exodus 25-31 consists of the instructions YHWH gave Moses during his fourth ascent of the mountain. It is reasonable to infer, therefore, that the sִבְְנִית was shown to Moses on this occasion. The story of Exod 24:9-18 suggests that other representatives of Israel did not have more than a glimpse of the heavenly temple, of which only the pavement is mentioned. Only Moses was allowed to ascend to the very place where YHWH was standing. This implies that he was shown many more details not available to the others, and it was during that time, that Moses received instructions for the construction of the tabernacle in the wilderness.

As noted by Kim, the fourth ascent of Moses has distinctive features that set it apart from the previous ascent narrative. ${ }^{5}$ Aaron is presented in the spotlight, possibly to demonstrate that the present narrative will focus on the sanctuary. It is in this narrative that the representatives of the people had a glimpse of the heavenly sanctuary. Besides, this fourth ascent contains more salient sanctuary overtones than the previous ones. The arrangement of the sacred space in which a limited group of people could go up to a certain point on the mountain, and only Moses could go up to the top, recalls the sanctuary. Furthermore, as Kim observed, that the reference to the

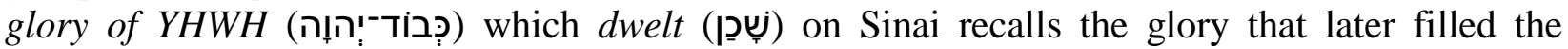
Tabernacle (מִִּ̣), as indicating on the following sentence: ${ }^{6}$

\section{Exod 24:16a}

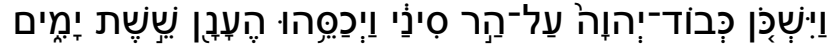

And the glory of the LORD rested on Mount

Sinai, and the cloud covered it for six days

\section{Exod 40:34}

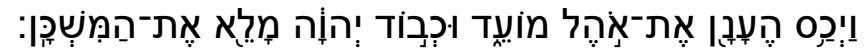

Then the cloud covered the tent of meeting, and the glory of the LORD filled the tabernacle.

${ }^{4}$ For example, the earthly sanctuary/temple is portrayed in the Hebrew Bible not only as mere place of dwelling of YHWH, but also as a place where YHWH is enthroned as king (see, e.g. Am 1:2; Ps 99:1-2) and executes judgment. The earthly sanctuary/temple is also portrayed as a place of atonement (see, e.g. Lev 16), as a place of worship (Isa 62:9; Ps 99:9; Ezra 3:10), a source of help (see, e.g. Ps 20:2). Furthermore, the sanctuary/temple is also related to the covenant (Exod 19-26; Ezek 37:26; $1 \mathrm{Kgs}$ 6:19), and may be an object of attack by the enemies (see, e.g. Dan 1:1-2).

${ }^{5}$ Sanglae Kim, "The Heavenly Sanctuary/Temple in the Hebrew Bible," PhD Dissertation (University of Sheffield, 2002), 78-100.

${ }^{6}$ Ibid. 
This parallel evoking sanctuary imagery where Moses had entered probably intended to show that by ascending the mountain fourth time, the sanctuary is equivalent of the heavenly sanctuary. Freedman argued that Moses was invited to the heavenly sanctuary, "the true tabnith, the sanctuary which served as a model for all replicas." "Although Freedman is most probably right in that Moses saw the heavenly sanctuary, the same cannot be said in regard to his view of

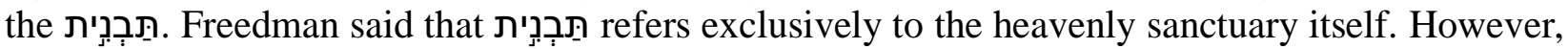
this is difficult to sustain when other references about the heavenly temple are taken into consideration.

In contrast to Freedman's view, Davidson observed, "Elsewhere in Scripture, the heavenly sanctuary is described as a vast, majesty temple, accommodating countless angels," 8 an observation corroborated by texts such as Isa 6:1; Ps 11:4; and Dan 7:9-14. Moreover, one should hold in mind that since the earthly sanctuary should be built according to the reasonable to suppose that a miniature model would be much closer to the entity that should be built on earth and, therefore, would be more effective from an instructional point of view. This model was presented in the context of Moses' experience on the top of the mountain, which included a vision of the heavenly sanctuary, as implied in Exod 24:9-11. If this is the case, it may be argued that מַבְבְנית bespeaks of a structural correspondence between the heavenly original and its earthly counterpart.

\section{Semantic and Exegetical Consideration}

\section{Semantic Analysis}

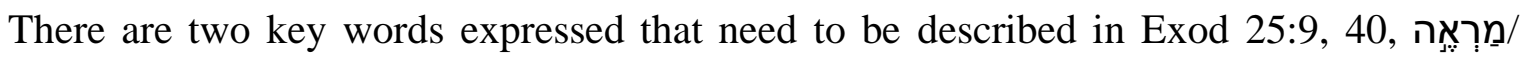

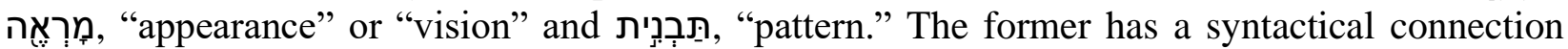
with the later. For instance, as indicated in Exod 25:9, God commanded Moses to build a sanctuary according to the pattern of what he had seen on the Mount Sinai. In Num 8:4, the Hebrew word מַרְֶֶה which means a "view" or "appearance." The following discussion indicates the semantic correlation these two terms.

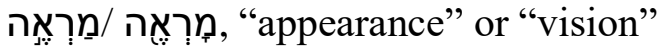

These two texts consist of God's command to Moses to build a sanctuary according to the תַּבְבְנית of what he had seen on the mount of Sinai. There are two verbs referring to God as the

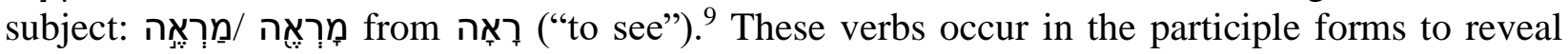

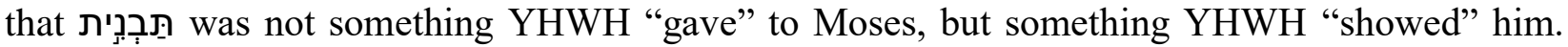
This implies "that Moses beheld a visible reality." 10 Thus, when Moses came down from the

${ }^{7}$ David Noel Freedman, “Temple Without Hands," in Temples and High Places in Biblical Times,21-30 (Jerusalem: The Nelson Glueck School of Biblical Archaeology of Hebrew Union College, 1977), 28.

${ }^{8}$ Richard M. Davidson, "Typology in in the Book of Hebrew" in Issues in the Book of Hebrews, ed. Frank B. Holbrook, 121-186 (Silver Spring, MD: Biblical Research Institute, 1989) 385.

${ }^{9}$ The Brown Driver Briggs Hebrew and English Lexicon (BDB), s.v. "רָָָ."

${ }^{10}$ Davidson, Typology in Scripture, 376. 


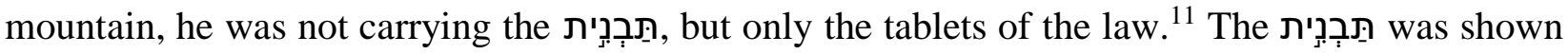
during his stay there, which, according to the narrative context, lasted "forty days and forty nights" (Exod 24:18).

The narrator in Num 8:4 indicates that Moses made everything "according to the vision"

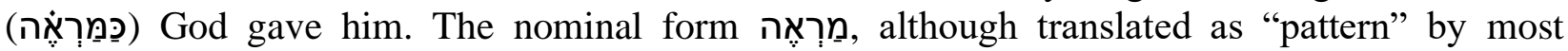
English versions, ${ }^{12}$ is plausible rendered as "appearance" or "vision. "13 This term also occurs in Exod 24:17 to report that "the appearance (מַרְֶֶ) of the glory of God was like a consuming fire

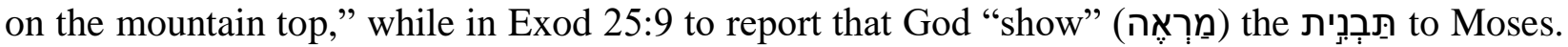
It may thus, be argued that the term מַרְִ in Num 8:4 and Exod 24:17 most probably indicates that the תַבְנָנית was shown to Moses in the context of a visual or vision experience. ${ }^{14}$ Such an interpretation accords better with the semantic connotation of the participle form of ממרְֵֶ/ מָרְאֶ used in Exod 25: 9, 40, and with the narrative context of Exod 24:9-18 as well.

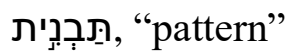

The term בָּבְבְנית ("built") and occurs twenty times in the Hebrew Bible. It is categorized by $B D B$ as construction, structure, pattern, figure, and image. ${ }^{15} H A L O T$ defines it as pattern, model, copy, reproduction, image, representation, something like, and architectural plan. ${ }^{16}$ Davidson, in his dissertation, defined the meaning of תַבְנִנית in the vertical correspondence (that is to say, earth-heaven correspondence). He proposed five possible interpretations of בַּבְבָנית under three German terms: Urbild, Vorbild, and Nachbild. That is to say, תַּבְנִנית may refer to an original entity (Urbild), a model to be copied (vorbild), or a copy of another entity (Nachbild). ${ }^{17}$

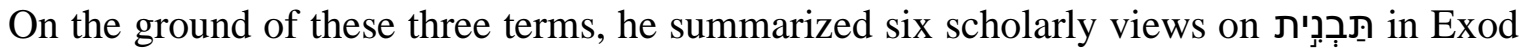
$25: 9,40$. Here it is constructed to five. First, God might show the copy (vorbid) of earthly sanctuary in miniature model. In this case, Moses would not necessarily have seen the heavenly sanctuary itself. Second, God might show the copy (vorbid) of the heavenly sanctuary in the form of miniature model. This implies that Moses would not necessarily have seen the heavenly sanctuary as it really existed. Third, Moses might have been shown the heavenly sanctuary itself (Urbild) and then was provided with a miniature model of it (vorbid) for constructing the earthly sanctuary. Fourth, God might show to Moses the heavenly sanctuary itself (urbild) without the miniature model. Fifth, Moses was not shown either the heavenly sanctuary (urbild) nor its miniature model (vorbild); rather, he was given subjective vision, the recollection of which he was to use in building the earthly sanctuary (nachbild). This last argument implies that Moses does not require the existence of a heavenly sanctuary. ${ }^{18}$

${ }^{11}$ Davidson has aptly said: If Moses had been shown merely architect's plans, it would be seen likely that these plans would have been made available to take down from the mountain so that the builder would follow them." Ibid, 376.

${ }^{12}$ E.g., NASB, NIV, NJB, NKJ, RSV, NRSV.

${ }^{13}$ BDB, s.v. "רָאָָה." It is worthy of note that the prepositional phrase places outside Num. 8:4, and almost always refers to "appearance" vision contexts. Cf. Lev 13:43; Num 8:4; 9:15; Judg 13:6; Ezek 1:13, 26; 8:2, 4; 10:1; 40:3; 41:21; 42:11; 43:3; Dan 8:15; 10:6; Joel 2:4. The only exception seems to be Lev. 13:43, which refers to the "appearance" of leprosy.

${ }^{14}$ Davidson, Typology in Scripture, 375.

${ }^{15}$ BDB, s.v. "בָּבְָה."

${ }^{16}$ The Hebrew and Aramaic Lexicon of the Old Testament, 386.

${ }^{17}$ Davidson, Typology in Scripture, 372-373.

${ }^{18}$ Ibid. 
From these various options, Davidson had difficulty to decide with certainty whether the primary reference of הַבְבְנית is to the miniature model of the heavenly sanctuary, to the heavenly sanctuary itself, or both." ${ }^{19}$ However, he personally affirmed that Moses was given a glimpse of the heavenly sanctuary, then he was provided with a miniature model a pattern to copy in constructing the earthly. ${ }^{20}$ At this point, the question concerning the physical relationship between miniature model and the heavenly original itself raises a problem since Davidson's discussion focuses more on the structural than theological relationship.

\section{Syntax Analysis}

Text says,

Exod 25:9

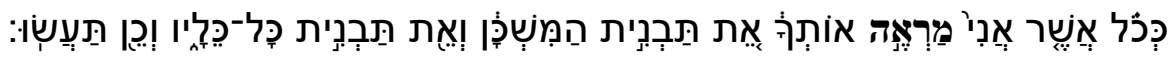

According to all that I am going to show you, as the pattern of the

tabernacle and the pattern of all its furniture, just so you shall construct it.

\section{Exod 25:40}

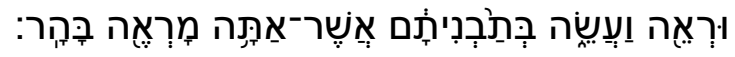

And see that you make them after the pattern for them, which was shown to you on the mountain.

The text indicates that הַבְבְנית in Exod 25:9 reappears in verse 40, at the end of an extended description of the ark of covenant, the table of showbread, and the golden lampstands. ${ }^{21}$ These pieces of furniture are mentioned certainly due to their appearance in the heavenly sanctuary. There is a reverse order in the discourse, where the two subordinate clauses come first then enclosed with main clause, as follows,

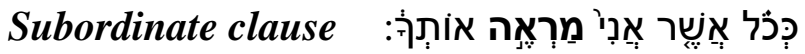

(Verbal Clause)

According to all that I am going to show you

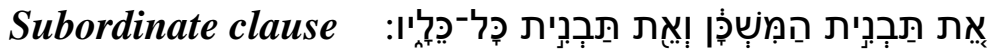

(Nominal Clause) as the pattern of the tabernacle and the pattern of all its furniture

\section{Main clause \\ (Verbal Clause) just so you shall construct it}

In the first subordinate clause, the verb מִרְִ "show" occurs in hiphil form, which simply means God caused Moses to see actively something that He was about to show. In Exod 25:40, the first use of this verb occurs in qal-imperative form fulfilled by Moses in constructing the Tabernacle. It is important to note that the prepositional phrase in the beginning of the clause

${ }^{19}$ Ibid., 386.

${ }^{20}$ Ibid., 378, 385.

${ }^{21}$ Douglas K. Stuart, Exodus, The New American Commentary 2, ed. E. Ray Clendenen (Nashville, TN: Broadman and Holman, 2006), 565, 566. 
agreement of construction in quantity and kind (e.g. Deut 1:11) or to indicate the correspondence of construction with regardless the quantity and kind (e.g. Neh 7:2). Syntactically, it is possible to

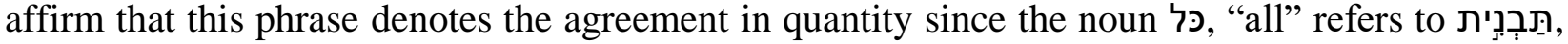

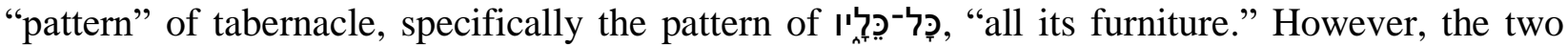
direct object markers object of transitive verbs. It means that the clause, which follows this marker, appears as the object of a certain verb, as indicated on the following feature:

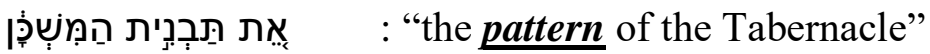

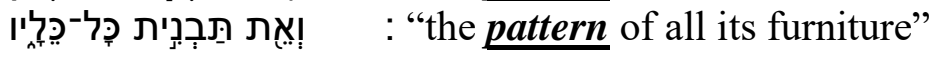

Syntactically, these two nominal clauses, which occur in juxtaposition, stand as the definite direct

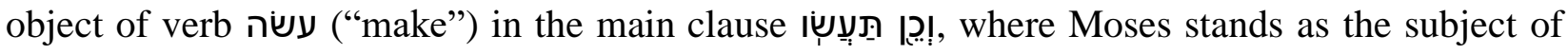
the verb. In this case, the direct object marker אֵת is followed by construction simply attests to the fact that מָבְבְנית hastus constructus with the following noun,

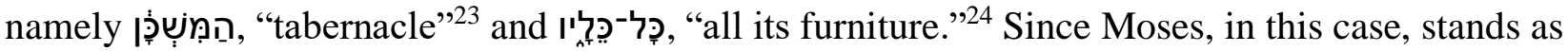
the recipients of God's command, both nouns, "tabernacle" and "all its furniture" are objects that should be built according to תַּבְבְנית that God was about to show to Moses.

In the light of the above syntactical connection, the context of this oracle does not support the position that the particle preposition ? ("like, as, according") denotes a sense of agreement either in quantity or measure. The quantity and measure of heavenly sanctuary exist in contrast with the earthly sanctuary. Hence, it is most probably, the preposition particle ?ุ in the first clause of this oracle serves as the comparison that establishes an equivalent between two temples/tabernacles that are compared. ${ }^{25}$ To this point, Waltke noted that the verb "show" occurs in hiphil form simply to denote that God caused Moses to see the pattern and build the sanctuary according to the pattern. ${ }^{26}$ Accordingly, the hophal form in Exod 25:40 indicates a causative passive sense of the verb, which means that Moses is caused by God to see the sanctuary on the mountain. ${ }^{27}$

${ }^{22}$ For more discussion of the morphology and the syntax of direct object marker, see Christo H. J. van der Merwe, Jackie A. Naude and Jan H. Kroeze, A Biblical Hebrew Reference Grammar, Biblical Language: Hebrew 3, ed. Stanley E. Porter, Richard S. Hess (Sheffield, Eng: Sheffield Academic Press, 1999), 245-247.

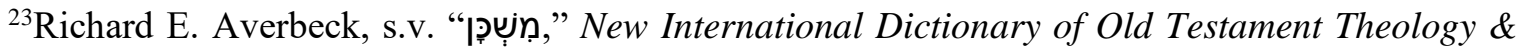
Exegesis 2 (NIDOTTE), ed. Willem A. VanGemeren (Grand Rapids, Michigan: Zondervan, 1997), 1132, 1133.

192.

${ }^{24}$ van der Merwe, Jackie A. Naude and Jan H. Kroeze, A Biblical Hebrew Reference Grammar,

${ }^{25}$ For the same syntactical feature, see Neh 7:2; Isa 24:2. F. Brown, S. Driver, and C. Briggs, The Brown-Driver-Briggs Hebrew and English Lexicon (BDB) (Peabody, Mass.: Hendrickson Publishers, Inc., 2007), 453, 454; Bill T. Arnold, John H. Choi, A Guide to Biblical Hebrew Syntax (Cambridge: Cambridge University Press, 2007), 109.

${ }^{26}$ Bruce K. Waltke, M. O'Connor, An Introduction to Biblical Hebrew Syntax (Winona Lake, Ind.: Eisenbrauns, 1990), 451. Cf. BDB, 906.

${ }^{27}$ Ibid., cf. Gen 33:11. For another example of hophal verb form in transitive sentence with passive causalities sense, see Exod 24:10; 29:7; Lev 21:10. 
Hitherto, the syntactical feature of this text does not reveal succinctly the relationship between heavenly and earthly sanctuary. In his scholarly article, Leeuwen has given an initial glimpse of that relationship in idiomatic connection. He attests that Moses makes the tabernacle according to a heavenly model. It is similar to God makes Adam according to a heavenly model (see Gen 1:26). ${ }^{28}$ His argument is reinforced by the idea that term תַּבְנִּית is isomething built" such as a model or plan for builder (cf. $2 \mathrm{Kgs} \mathrm{16:10;1} \mathrm{Chr} \mathrm{28:19).} \mathrm{The} \mathrm{end} \mathrm{product} \mathrm{of} \mathrm{building} \mathrm{or}$ thing (such as in Josh 22:28) constructed in resemblance of something (cf. Deut 4:16-18). Thus, Exod 25:9, 40 and Gen 1:26 simply mean "to make $\boldsymbol{A}$ in conformity to $\boldsymbol{B}$." ${ }^{\text {"29 }}$

Clines has rejected Leeuwen's argument on the ground that God has no form, and humankind is not made in God's image, but rather as God's image. Thus, humanity is God's representative and agent on earth. Consequently, the expression "likeness" guarantees that humans will be faithful and adequate representatives of God on earth. Humans embody "God's lordship over the lower orders of creation." ${ }^{30}$ In this case, he insisted that humans in the image of God exist to carry out God's purposes on earth as his royal representatives. Thus, the meaning of the image does not lie in the mere terms used, but in Israel's understanding of representative. ${ }^{31}$ However, the arguments of Leeuwen and Clines are subtle from the outset since they construe that the הַּבְנִנית refers to the structural/form not theological relationship of heavenly and earthly sanctuary.

To find the glimpse relationship, it is necessary to see the parallel semantic of the term from the immediate context. In Exod 26:30, God reminds Moses to build the tabernacle "according to the טמ̣: (plan)," which has been shown to Moses on the mountain. The lexical meaning of this word is "judgment" or "rule"; however, the context indicates the parallel meaning

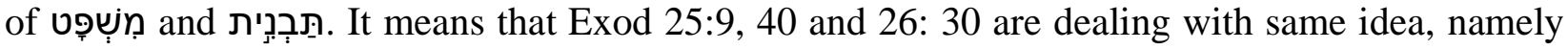

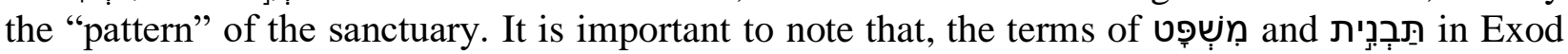
27:1-8 are totally absent in the command of God to make the furniture of tabernacle, such as the altar, pails, shovels, forks, and fire pans. On the ground of this fact, it is tangible to conclude that though the instruments of the tabernacle are just described following the pattern given to Moses on the mountain, they are not to be found in heaven. In affirming this argument, Roy Adam insisted that this conclusion is supported by the actual outworking of the antitype. ${ }^{32}$ It means that

\footnotetext{
${ }^{28}$ Raymond C. Van Leeuwen, "Form, Image," New International Dictionary of Old Testament Theology \& Exegesis 4 (NIDOTTE), ed. Willem A. VanGemeren (Grand Rapids, Michigan: Zondervan, 1997), 644, 646.

${ }^{29} \mathrm{Ibid}$. For example, the syntactical feature of Exod 25:40 indicates that the verb is followed by

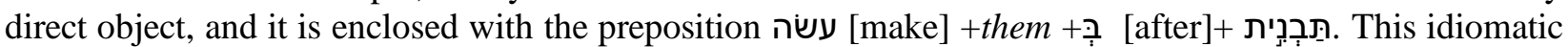
expression obviates an appeal to the "image" in Gen. 1:26. Thus, he concludes that God did not make human to be his image, nor in the likeness of a heavenly image other than himself. Cf. C. John Collins, Genesis 1-4: A Linguistic, Literary, and Theological Commentary (Phillipsburg, New Jersey: 2006), 6167; John H. Sailhamer, The Pentateuch as Narrative: A Biblical-Theological Commentary (Grand Rapids: Zondervan Publishing House, 1992), 97, 98.

${ }^{30}$ D. J. A. Clines, "The Image of God in Man," Tyndale Bulletin (1968), 101, 102. Cf. Robert H. Gundry, Commentary on the New Testament: Verse-by-Verse Explanations with a Literal Translation (Peabody, MA: Hendrickson, 2010), 892.

${ }^{31}$ Ibid.

${ }^{32}$ Adam insisted that Calvary represents the antitypical altar of burn offerings. It is there that the Lord Jesus was offered up, but how different in physical form it was from its typical counterpart. Moreover, he insists that the sacred courtyard ringed with curtains; in the antitype, the naked, unconsecrated hill of Calvary. In the type, an altar is made of bronze, in the antitype, it is made of a
} 
the parallels between the heavenly and earthly sanctuary are real, but the contrasts are equally sharp and pointed. Thus, it is impossible to make one-on-one correspondence between earthly and heavenly sanctuary. ${ }^{33}$

In the broader context, the nature of correspondence of earthly and heavenly sanctuary runs from the type (original) to the antitype (copy), as indicates in Heb 8:5; 9:24. Here "a copy

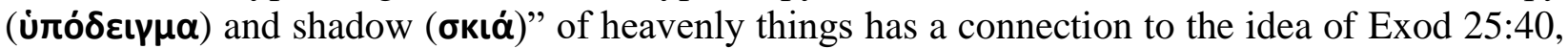
in which God enjoined Moses to construct the tabernacle and all its appurtenances "according to the pattern (זúros) which is shown you on the mountain." 34 Thus, here three terms have been

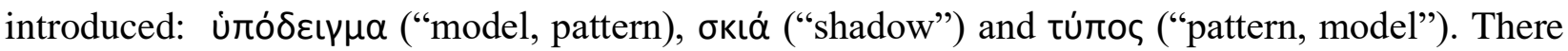
are three implications in the use of these three terms. First, the Hebrew term תַבְבְנית (Exod 25:40)

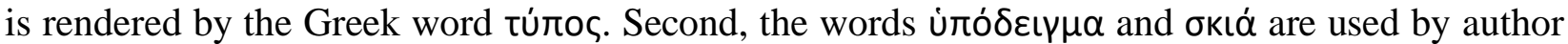
to explain the relationship between the earthly and heavenly ministries. ${ }^{35}$ It means that these two

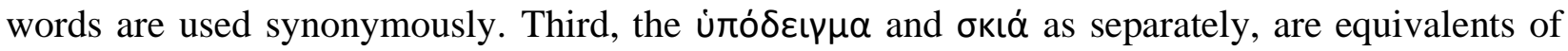

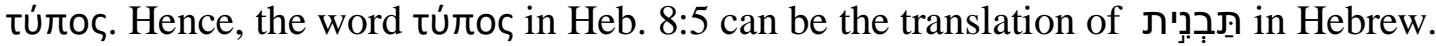

On the ground of this argument, the limitation of the law in Heb 10:1 is based on the fact

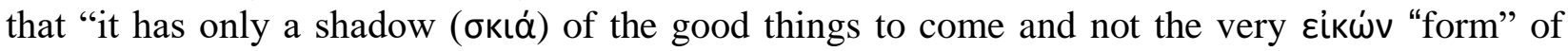

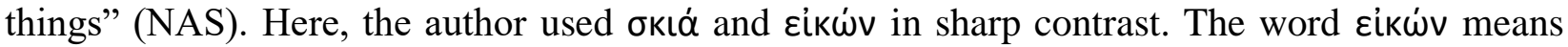
"form" or "appearance," צלִ ("image"). This word has been employed to describe the physical and spiritual correspondence between God and man in the beginning, or between father and son (cf. Gen 1:26, 27; 5:3; Col 1:15). Thus, if a spiritual instinct deters us from dogmatizing even where we have a strong عícúv ("form")

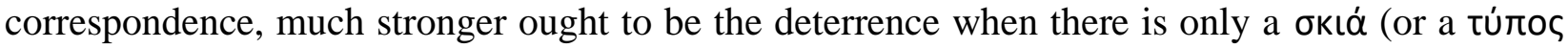

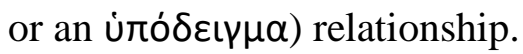

The point is that, we should struggle to show not how much things in heaven resemble those on earth but how different and inferior things on earth are when set against the heavenly reality or archetype. ${ }^{37}$ The different structure of the tabernacle and the Jerusalem example does not subordinate the meaning of בַבְבנִית. For example, the temple of Jerusalem consists of, at least two courts, not just one, as in the wilderness tabernacle (2 Kgs 21:5; 23:12; $2 \mathrm{Chr} 4: 9 ; 1 \mathrm{Kgs}$ 6:36; Jer 36:10). There was only one entrance to the court in the wilderness tabernacle, where six gates led into the precincts of Jerusalem temple (1 Chr 9:18; Jer 26:10; 36:10; $1 \mathrm{Kgs} 15: 35) .{ }^{38}$

wooden cross. For more discussion on this point, see Roy Adams, The Sanctuary: Understanding the Heart of Adventist Theology (Hagerstown: Review and Herald Publishing Association, 1993), 47.

${ }^{33}$ William G. Johnson, In Absolute Confidence: The Book of Hebrew Speak to Our Day (Nashville: Southern Publishing Association, 1979), 91.

${ }^{34}$ Kenneth S. Wuest, "Hebrew in the Greek New Testament" in Wuest's Word Studies From the Greek New Testament 2 (Grand Rapids, MI: Eerdmans, 1978), 141.

${ }^{35}$ Siegried Schulz, "бкı́a," Theological Dictionary of the New Testament, ed. Gerhard Kittel, Gerhard Friedrich (Grand Rapids, MI: Eerdmans, 1982), 7: 395-398. See also Raymond, C. Van Leeuwen, "Form, Image," NIDOTTE 4, 646.

${ }^{36}$ W. F. Arndt and F. W. Gingrich, A Greek-English Lexicon of the New Testament and Other Early Christian Literature (Chicago: University of Chicago Press, 1979), 213, 214.

${ }^{37}$ Roy Adams, The Sanctuary, 49, 50.

${ }^{38}$ Another difference is indicated, the wilderness tabernacle contained one lampstand on the south side and one table of showbread on the north. By contrast, the Jerusalem temple contained 10 lampstands and 10 tables of showbread on the both saides, north and south (2 Chr 4: 7, 8). Adam, Roy Adams, The Sanctuary, 52. 


\section{Summary and Conclusion}

\section{Summary}

In view of the purpose of this article, the falls into three points. First, the wilderness

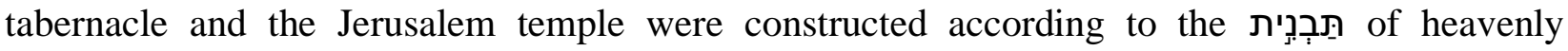
sanctuary. It means the meaning of this word is not strictly understood in the literal sense since many details the two structures exhibit such striking dissimilarities. The implication is obvious God gave the blueprint to both Moses and David to build the tabernacle/ temple, regardless of the difference. Thus, the difference of the temple ought to steer us away from dogmatizing about the exact appearance of the heavenly sanctuary based on our knowledge of the earthly sanctuary.

Second, it is not the structural details of the tabernacle/temple that are most important. Rather, it is the basic plan, specifically the three-basic representation of the sanctuary in the OT, regardless of the other variants. All three (the tabernacle in the wilderness, the temple of Solomon, and the temple of Ezekiel) consist of three basic divisions: the court, the holy place, and the Most Holly place. The basic equipment and furniture of each were the same, in the courtyard: the altar of burn offerings; in the holy place: the lampstands, tables of showbread, and the incense altar; in the Most Holy place: the sacred ark, overshadowed by the golden cherubim. It represents the three dimensions of the plan of salvation, namely the atonement, intercession, and judgment.

Third, the physical appearance of the earthly tabernacle/temple gives us no warrant to dogmatize on the physical appearance of the heavenly original. The safer approach is to concentrate on the theological significance, rather than on the structural specification. This means that we do not look for heavenly counterparts for the boards, loops, sockets, grills, basins and, the numerous other paraphernalia that formed part of the earthly sanctuary complex.

\section{Conclusion}

Semantically, the idea of תַּבְבְנית attests to the fact that there is correspondence between the heavenly sanctuary and its earthly counterpart. In the light of this presupposition, some Biblical scholars proposed various levels of that correspondence. Although their argument are slightly different to this correspondence but they agree in one point, that there is a structural relationship between the heavenly and earthly sanctuary. Syntactically, it is possible to affirm that the

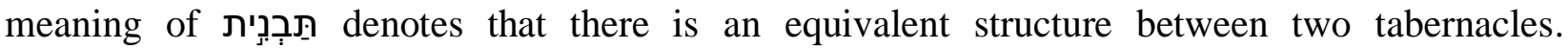
However, this connection does not ignore the fact that there are differences between heavenly and earthly sanctuary. In other words, the idea of תַבְבְנית in the relationship of these two sanctuaries should be viewed from idiomatic connection, not in one-on-one correspondence. The parallels between the heavenly and earthly sanctuary are real, but the contrasts are equally sharp and pointed. It means, the instruments of the tabernacle are just described following the pattern (תַּבְנִית) given to Moses on the mountain, they are not to be found in heaven. Thus, it is futile to speculate as to the dimensions, exact appearance, or precise arrangement of the heavenly sanctuary. To this point, White said, "no earthly structure could represent its vastness and its glory." 39

${ }^{39}$ E. G. White, Patriarch and Prophets, 357. See also Francis D. Nichol, ed., 'after the pattern" SDA BC 1 (Hagerstown, MD: Review and Herald, 1978), 636; Milian Lavritz Andreasen, The Sanctuary Service (Hagerstown, MD: Review and Herald, 1947), 23-38. Cf. Peter Enns, Exodus, The NIV Application Commentary, ed. Terry Muck (Grand Rapids, MI: Zondervan, 1961), 508, 509. 